Volume 10. Nomor 2. December 2015
Pandecta
http://journal.unnes.ac.id/nju/index.php/pandecta

\title{
Penyelesaian Perselisihan Hubungan Industrial di Pengadilan Hubungan Industrial dalam Pemenuhan Hak Pekerja/Buruh Yang di Putus Hubungan Kerja
}

\author{
Yani Nur Fatimah
}

Fakultas Hukum Universitas Negeri Semarang, Semarang, Indonesia

Permalink/DOI http://dx.doi.org/10.15294/pandecta.v10i2.

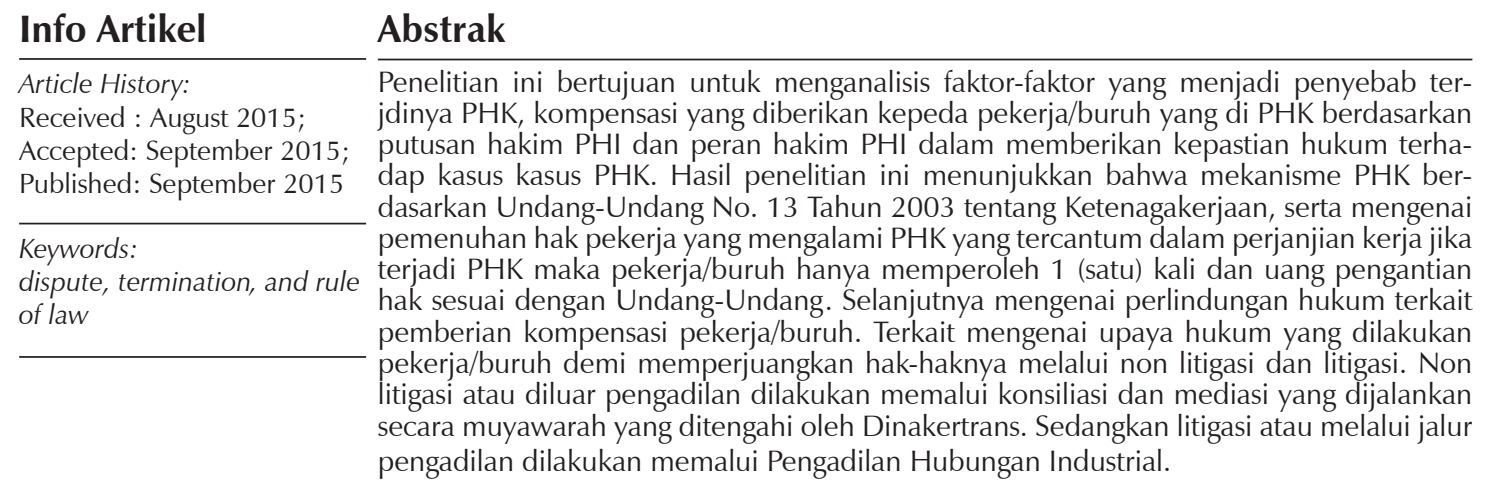

\section{Abstract}

This study aimed to analyze the factors that cause terjdinya layoffs, compensation provided kepeda workers / laborers whose employment is terminated by the judge's ruling and the role of judges PHI PHI to provide legal certainty to the cases of layoffs. These results indicate that the mechanism of layoffs under Law No. 13 of 2003 on Labor, as well as the fulfillment of the rights of workers who were laid off were contained in employment contracts in the event of layoff the workers / laborers only get 1 (one) time and money replacement right in accordance with the Law. Furthermore, regarding the legal protection related to compensation of workers / laborers. Related legal efforts undertaken regarding workers / labor for asserting their rights through non-litigation and litigation. Non litigation or outside court is performed by the conciliation and mediation run muyawarah brokered by Dinakertrans. While litigation or through the courts is performed by the Industrial Relations Court. 


\section{Pendahuluan}

Perselisihan hubungan industrial disebut juga dengan perselisihan perburuhan sebagai mana diatur dalam Undang-Uundang Nomor 2 Tahun 2004 tentang Penyelesaian Perselisihan Hubungan Industrial yang merupakan perbedaan pendapat yang mengakibatkan pertentangan antara pengusaha atau gabungan pengusahan dengan pekerja/buruh atau serikat pekerja/buruh karena ada perselisihan mengenai hak, perselisihan kepentingan dan perselisihan pemutusan hubungan kerja atau perselisihan antar pekerja/serikat buruh hanya dalam satu perusahaan.

Setiap orang selalu membutuhkan biaya untuk memenuhi kebutuhannya. Untuk mendapatkan biaya hidup seseorang perlu bekerja. Bekerja dapat dilakukan secara mandiri atau bekerja pada orang lain. Bekerja kepada orang lain dapat dilakukan dengan bekerja pada negara yang selanjutnya disebut dengan pegawai atau bekerja pada orang lain (swasta) yang disebut dengan buruh atau pekerja.

Setiap pekerja/ buruh mempunyai hak dan kewajiban sebagai mana diatur dalam Undang-Undang Republik Indonesia Nomor 13 Tahun 2003 Tentang Ketenagakerjaan dan Undang-Undang lainnya serta Peraturan Pemerintah yang berkaitan dengan Ketenagakerjaan, dimana hak pekerja/buruh merupakan suatu hal yang selayaknya diterima oleh pekerja sesuai kesepakatan atau perjanjian dengan pihak pemberi kerja (Midah, 2010; Libertus, 2007; Marbun, 2010). Sedangkan kewajiban merupan sesuatu yang wajib dijalankan atau dilaksanakan oleh pekerja sesuai dengan kesepakatan atau perjanjian dengan pihak pemberi kerja. Dengan melaksanakan hak dan kewajibannya, antara pekerja dan pemberi kerja berarti telah memenuhi apa yang sudah disepakati bersama atau sudah diperjanjikan, masing-masing pihak telah memenuhi prestasinya.

Pemutusan Hubungan Kerja (PHK) merupakan suatu hal yang merupakan kegiatan yang sangat ditakuti oleh pekerja/buruh yang masih aktif bekerja.Hal ini karena kondisi kehidupan politik yang goyah, kemudian disusul dengan carut marutnya kondisi perekonomian yang berdampak pada banyaknya industri yang gulung tikar dan tentu saja berdampak pada pemutusan hubungan kerja yang dilakukan dengan sangat tidak terencana.Kondisi inilah yang menyebabkan orang yang bekerja pada waktu ini selalu dibayangi kekhawatiran dan kecemasan, kapan giliran dirinya diberhentikan dari pekerjaannya yang menjadi penopang hidup keluarganya.

Faktanya pemutusan hubungan kerja yang terjadi karena berakhirnya waktu yang telah ditetapkan dalam perjanjian kerja, tidak menimbulkan permasalahan terhadap kedua belah pihak (pekerja/buruh maupun pengusaha) karena pihak yang bersangkutan sama-sama telah menyadari bahwa atau mengetahui saat berakhirnya hubungan kerja tersebut sehingga masing-masing telah berupaya mempersiapkan diri menghadapi kenyataan itu. Berbeda halnya dengan pemutusan yang terjadi karena adanya perselisihan, keadaan ini akan membawa dampak terhadap kedua belah pihak, lebih-lebih yang dipandang dari sudut ekonomis mempunyai kedudukan yang lemah jika dibandingkan dengan pihak pengusaha (Zaeni, 2008).

Sehubungan dengan dampak PHK sangat kompleks dan cenderung menimbulkan perselisihan, maka mekanisme prosedur PHK diatur sedemikian rupa agar pekerja/buruh telah mendapatkan perlindungan yang layak dan memperoleh hak-haknya sesuai dengan ketentuan. Perlindungan pekerja tersebut dalam Bahasa Belanda disebut arbeidsbescherming. Maksud dan tujuan perlindungan buruh atau perlindungan pekerja adalah agar pekerja dapat dilindungi dari perlakuan pemerasan oleh pihak pengusaha. Pemerintah sangat menaruh perhatian terhadap masalah perlindungan pekerja/buruh karena pada umumnya posisi pekerja masih lemah, sehingga perlindungan kerja dan kesalamatan kerja akan dapat mewujudkan terpeliharanya kesejahteraan, kesehatan, kedisplinan pekerja yang berada di bawah pimpinan pengusaha (Zainal dkk., 1994).

Mengenai perlindungan hak-hak pekerja/buruh ini yaitu apakah pesangon yang diberikan pengusaha sudah memadai atau belum. Apablia pemberian uang pesangon 
sudah sesuai dengan peraturan perundangundangan yang berlaku, maka tidak ada permasalahan. Tetapi apabila dilihat dari keadaan si buruh, maka ketika si buruh yang besangkutan mengalami PHK, maka untuk ke depannya buruh tersebut sudah tidak mendapat pemasukan lagi. Maka disini terlihat bahwa pesangon bukan merupakan hal utama, melainkan keamanan dalam bekerja, yang dalam artian bahwa ketika buruh bekerja buruh tersebut merasa khawatir bahwa sewaktu-waktu dia akan mendapat PHK. Disinilah peranan undang-undang memainkan peranan penting, yaitu sebagai pelindung buruh (Sunyoto, 2010). Namun sayangnya UU No. 13 Tahun 2003 tentang Ketenagakerjaan sebagai regulasi perburuhan terbaru justru tidak mampu mengakomondasikan hal ini. Justru undang-undang sebelumnya secara tegas menyatakan bahwa PHK merupakan hal yang dilarang.

Pada kenyataannya, jangankan untuk memperoleh kehidupan yang layak.Untuk memperoleh pekerjaan, jaminan hidup ataupun perlindungan masih jauh dari harapan. Malahan, buruh atau pekerja yang sudah memiliki pekerjaan (walau ala kadarnya) dalam prakteknya sangat mudah kehilangan pekerjaan dengan cara Pemutusan Hubungan Kerja (PHK).

Tetapi tidak jarang dapat kita temukan banyak pekerja/buruh setelah mereka terkena PHK, pekerja/buruh kadang meminta kepada pihak pengusaha/perusahaan untuk dibayarkan hak-hak mereka melebihi apa yang diatur dalam ketentuan yang berlaku. Dengan kondisi inilah yang membuat persoalan penyelesaian perselisihan PHK sulit diselesaikan (Sidabutar, 2004).

Atas dasar hal-hal tersebut di atas, penulis tertarik untuk mengkaji dua persoalan utama dalam artikel ini. Pertama tentang pelaksanaan Undang-Undang Nomor 2 Tahun 2004 Tentang Penyelesaian Perseliaihan Hubungan Industrial (hukum formil) terhadap pemenuhan hak pekerja/buruh yang mengalami PHK di Pengadilan Hubungan Industrial. Kedua tentang perlindungan hukum terhadap hak pekerja/buruh terkait pelaksanaan pemberian kompensasi terhadap pekerja/ buruh yang sesuai dengan Undang-Undang
Nomor 13 tahun 2003 Tentang Ketenagakerjaan (hukum materil) dalam putusan menganai perselisihan PHK di Pengadilan Hubungan Industrial yang telah berkekuatan hukum tetap (BHT).

\section{Metode Penelitian}

Pendekatan penelitian ini diharapkan dapat menganalis menganai Pelaksanaan Undang-Undang Nomor 2 Tahun 2004 Tentang Penyelesaian Perselisihan Hubungan Industrial Di Pengadilan Hubungan Industrial Semarang Tarhadap Pemenuhan Hak Pekerja/ Buruh Yang Di PHK Untuk Mendapatkan Pesangon.

\section{Hasil Penelitian dan Pembahasan}

\section{Pengadilan Hubungan Industria pada Pen- gadilan Negeri Semarang.}

Pengadilan Hubungan Industrial adalah Pengadilan khusus yang dibentuk di lingkungan peradilan umum yang berwenang mengadili dan menyelesaikan perselisihan hubungan industrial berdasarkan Undang-Undang Nomor 2 Tahun 2004 tentang Penyelesaian Perselisihan Hubungan Industrial. Beroperasinya Pengadilan Hubungan Industrial memiliki perubahan yang cukup mendasar. Pertama, penyelesaian perselisihan hubungan industrial yang selama ini berada di bawah lingkup wilayah eksekutif, kini menjadi bagian dari sistem peradilan di bawah kekuasaan yudikatif. Kedua, hukum acara Pengadilan Hubungan Industrial mengikuti hukum acara perdata yang berlaku pada Pengadilan dalam lingkungan peradilan umum, kecuali ditentukan lain dalam Undang-undang Nomor 2 Tahun 2004 tentang Penyelesaian Perselisihan Hubungan Industrial.

Pengadilan Hubungan Industrial dibentuk pada bulan Januari 2006 pada Pengadilan Negeri Semarang, dan begitu juga pada Pengadilan-Pengadilan Negeri yang lain disetiap Ibukota Propinsi di Indonesia. Pembentukan Pengadilan Hubungan Industrial seharusnya dilakukan pada awal tahun 2005 tapi ditunda berdasarkan Keputusan Presiden Nomor 1 Tahun 2005 tentang Penangguhan Mulai Berlakunya Undang-undang Nomor 2 Tahun 2004, untuk menambah waktu semua per- 
siapan yang dibutuhkan oleh pemerintah dan institusi lain yang terkait.

Adanya Pengadilan Hubungan Industrial menambah jumlah Pengadilan khusus yang berada di Pengadilan Negeri Semarang. Pengadilan Hubungan Industrial juga membawa perubahan pada struktur organisasi Pengadilan Negeri, yaitu dengan diperkenalkannya Sub Kepaniteraan Pengadilan Hubungan Industrial yang dipimpin oleh seorang Panitera Muda dan dibantu oleh beberapa orang Panitera Pengganti. Panitera Muda Hubungan Industrial berada sejajar dengan Panitera Muda Pidana, Perdata dan Hukum yang ada di Pengadilan Negeri. Selain itu sebagaimana halnya dengan Pengadilan Niaga dan Pengadilan Tindak Pidana Korupsi, Pengadilan Hubungan Industrial juga memiliki Hakim Ad Hoc untuk menjadi bagian dari Majelis yang memeriksa perkara. Hakim Ad Hoc diajukan oleh Ketua Mahkamah Agung dari nama-nama yang diajukan oleh Menteri Tenaga Kerja atas usul Serikat Pekerja/Serikat Buruh dan Organisasi Pengusaha. Pengangkatan Hakim Ad Hoc tersebut ditetapkan oleh Keputusan Presiden.

Satu hal lain yang diperkenalkan oleh Pengadilan Hubungan Industrial adalah dalam berperkara di Pengadilan Hubungan Industrial, pihak-pihak yang berperkara dengan nilai gugatan dibawah Rp. 150.000.000,- (seratus lima puluh juta rupiah) tidak dikenakan biaya perkara termasuk biaya eksekusi.

Pengadilan Hubungan Industrial merupakan pengadilan yang mempunyai wewenang khusus yang berada pada lingkungan peradilan umum. Pengadilan Hubungan Industrial bertugas dan berwewenang memeriksa dan memutus. Secara yurisdiksi, Pengadilan Hubungan Industrial perkara yang dapat di tangani adalah sebagai berikut: Pada tingkat pertama, Pengadilan Hubungan Industrial mengadili perselisihan hak dan perselisihan pemutusan hubungan kerja. Pada tingkat pertama dan terakhir Pengadilan Hubungan Industrial mengadili perselisihan kepentingan dan perselisihan antar serikat pekerja/serikat buruh.

Dalam menjalankan kewenangannya, pengadilan ini dilengkapi dengan Fungsionaris Pengadilan. Yang dimaksud dengan
Fungsionaris Pengadilan adalah orang-orang atau mereka yang berkedudukan atau jabatan dan tugasnya membuat pengadilan itu berfungsi sebagaimana mestinya atau dengan kata lain, Fungsionalis Pengadilan ialah para pejabat yang oleh negara telah disarahi tugas untuk menjadi penyelenggara atau pelaksana fungsi pengadilan sebagaimana mestinya. Visi dari Fungsional Pengadilan adalah Mewujudkan supremasi hukum melalui kekuasan kehakiman yang mandiri, efektif, efisien, serta mendapatkan kepercayaan publik, profesional dan memberikan pelayanan hukum yang berkualitas, etis, terjangkau dan biaya rendah bagi masyarakat serta mampu menjawab panggilan pelayanan publik. Sedangkan Misi utama dari Funsionaris Pengadilan adalah harus dapat berusaha dan menjamin agar pengadilan dalam fungsinya dapat mencapai dan mencerminkan keadilan, kewajiban hokum, perkembangan hokum, efisiensi dan efektivitas hokum, serta kesejahteraan kehidupan masyarakat.

\section{Pelaksanaan Undang-Undang Nomor 2 Tahun 2004 Tentang Penyelesaian Perse- liaihan Hubungan Industrial (hukum formil) terhadap pemenuhan hak pekerja/ buruh yang mengalami PHK di Pengadilan Hubungan Industrial.}

Pada prinsipnya, Undang-Undang Nomor 13 Tahun 2003 tentang Ketenagakerjaan (UU Ketenagakerjaan) dan Undang-Undang Nomor 2 Tahun 2004 tentang Penyelesaian Perselisihan Hubungan Industrial (UU PPHI) telah mengatur tentang apa saja keadaan dan bagaimana mekanisme pemutusan hubungan kerja (PHK).

Pasal 151 UU Ketanagakerjaan menjalaskan bahwa pekerja dan pengusaha harus berusaha semaksimal mungkin menghindari PHK. Kalaupun tidak bisa dihindari pekerja dan pengusaha harus berunding untuk mencari kesepakatan. Kalau perundingan itu mentok, maka PHK baru bisa dilakukan setalah ada penetapan dari lembaga penyelesaian perselisihan hubungan industrial.

Pemutusan hubungan kerja yang dilakukan tanpa persetujuan lembaga penyelesaian perselisihan hubungan industrial menjadi batal demi hukum. Artinya PHK itu 
dianggap sama sekali tidak pernah ada. Hal itu ditegaskan alam pasal 155 Ayat (1) UU Ketenagakerjaan (Budiono, 2011; Hardijan, 2011).

Ketika lembaga penyelesaian perselisihan hubungan industial masih memeriksa proses $\mathrm{PHK}$, pekerja dan pengusaha tetap harus melaksanakan kewajiban seperti biasa. Pekerja tetap bekerja, dan pengusaha tetap berkewajiban membayarkan hak pekerja. Hal itu tertuang dalam Pasal 155 Ayat (2) UU Ketenagakerjaan.

Ketika pengusaha dapat menjatuhkan skorsing alias pemberhentian sementara kepada pekerja yang sedang dalam proses PHK. Namun begitu pengusaha tetap berkewajiban membayar hak si pekerja. Demikian isi dari Pasal 155 Ayat (3) UU Ketenagakerjaan.

Secara normatif ditegaskan bahwa Undang-Undang Nomor 2 Tahun 2004 Tentang Penyelesaian Perselisihan Hubungan Industrial dibentuk dalam rangka mewujudkan hubungan industrial yang harmonis, dinamis dan berkeadilan serta menyikapi perkembangan industrialisasi yang mengakibatkan semakin meningkat dan kompleks perselisihan hubungan industrial (Wijayanti, 2009,
2012).

Pada asas berperkara di Pengadilan Hubungan Industrial tidak jauh berbeda dalam berperkara perdata di lingkungan peradilan umum pada umumnya, karena hukum yang dipakai oleh Pengadilan Hubungan Industrial adalah hukum acara perdata yang berkalu di lingkungan peradilan umum kecuali yang diatur secara khusus dalam Undang-Undang Nomor 2 Tahun 2004 Tentang Penyelesaian Perselisihan Hubungan Industrial

Berdasarkan data PHI pada PN Semarang Tahun 2006s/d 2014 adapun perkaraperkara yang masuk dapat dilihat pada table 1 tentang "Data Perkara PHI 2006-2014".

Berdasarkan hasil wawancara penulis dengan Daryono, seorang Hakim Ad-Hoc di Pengadilan Hubungan Industrial Semarang terkait mekanisme PHK berdasarka UndangUndang No. 13 Tahun 2003 Tentang Ketenagakerjaan pada Hari Rabu, 18 Maret 2015 Pukul 09.15 WIB, menyatakan bahwa :

"Pelaksanaan Undang-Undang Nomor 2 Tahun 2004 Tentang Perselisihan Hubungan Industrial Terhadap Pemenuhan Hak Pekerja/ Buruh Yang Di PHK Untuk Mendapatkan Pesangon. Peran

Tabel 1 Perkara-Perkara Sengketa Perburuhan di PN Semarang

\begin{tabular}{|c|c|c|c|c|}
\hline Tahun & $\begin{array}{c}\text { Perkara yg } \\
\text { Masuk }\end{array}$ & Kasasi & PK & Keterangan \\
\hline 2006 & 57 & 14 & & Dicabut $=6$ \\
\hline 2007 & 93 & 26 & - & Eksekusi $2006 \& 2007=36$ \\
\hline 2008 & 151 & 59 & 3 & $\begin{array}{l}\text { Dicabut }=10 \\
\text { Eksekusi }= \\
\text { Damai }=10\end{array}$ \\
\hline 2009 & 89 & 48 & 5 & $\begin{array}{l}\text { Dicabut }=1 \\
\text { Damai }=5 \\
\text { Eksekusi }=22 \\
\text { Dicabut }=25\end{array}$ \\
\hline 2010 & 122 & 54 & 6 & $\begin{array}{l}\text { Damai }=6 \\
\text { Eksekusi }=16\end{array}$ \\
\hline 2011 & 54 & 33 & 7 & $\begin{array}{l}\text { Dicabut }=13 \\
\text { Damai }=3\end{array}$ \\
\hline 2012 & 79 & 43 & 7 & $\begin{array}{l}\text { Dicabut }=27 \\
\text { Damai }=3\end{array}$ \\
\hline 2013 & 49 & 23 & 2 & $\begin{array}{l}\text { Dicabut }=10 \\
\text { Damai }=1\end{array}$ \\
\hline 2014 & 48 & 20 & 1 & Eksekusi $=113$ \\
\hline
\end{tabular}

Sumber: Data perkara PHI Tahun 2006 s/d 2014) 
Hakim Ad-Hoc pada PHI adalah memberikan solusi dan berusaha mendamaikan para pihak supaya tidak terjadi Perselisihan PHK."

Dalam memberikan solusi tersebut penulis berpendapat bahwa jika mekanisme PHK sudah sesuai dengan Undang-Undang Nomor 13 Tahun 2003 tentang Ketenagakerjaan, maka permasalahan PHK tidak akan sampai ke Pengadilan. Karena rata-rata tidak sesuai dengan apa yang diatur oleh UndangUndang, maka perkara tersebut masuk ke Pengadilan (Wawancara, 18 Maret 2015, di Pengadilan Hubungan Industrial Semarang).

Kebanyakan pelanggaran yang terjadi kerana PHK tersebut tidak sesuai dengan Undang-Undang Nomor 13 Tahun 2003 Tentang Ketenagakerjaan sebagai aturan dasarnya. Sebagai fundamentumnya Undang-Undang Nomor 13 Tahun 2003 Tentang Ketenagakerjaan tapi dalam kenyataan perjanjian kerja tersebut banyak yang bertentangan.

Menurut Daryono, hal yang menjadi perselisihan yaitu mekanisme PHK yang dilakukan oleh perusahaan tidak sesuai dengan Undang-Undang, atau mekanisme sesuai dengan Peraturan perusahaan tetapi tidak sesuai dengan Undang-Undang. Sehingga pertentangan dan perselisihan tersebut masuk ke Pengadilan. Yang menjadi permasalahan buruh pada saat bekerja tidak pernah melihat Perjanjian Kerja Perjanjian Perusahaan dan Perjanjian Kerja Bersama. Apakah kontraknya sudah sesuai dengan Undang-Undang apa tidak, yang terpenting bagi buruh bekerja dulu (Wawancara, 18 Maret 2015, di Pengadilan Hubungan Industrial Semarang).

Pekerja/buruh berani melakukan gugatan atau proses perlawanan terhadap perusahaan, dengan cara bergabung dengan suatu organisasi pekerja/buruh, atau dengan bergabung dengan $\mathrm{LBH}$ atau dengan di damping pengacara.

Sedangkan menurut Hening Wahyuningtyas, seorang PLH. PANMUD di Pengadilan Hubungan Industrial Semarang terkait mekanisme PHK berdasarkan Undang-Undang No. 13 Tahun 2003 Tentang Ketenagakerjaan pada Hari Rabu, 18 Maret 2015 Pukul 10.25 WIB, menyatakan bahwa :

\footnotetext{
“Berdasarkan Undang-Undang No. 13 Tahun
}

2003 Tentang Ketenagakerjaan makanisme PHK sudah sesuai dengan yang ada di Undang-Undang"

Secara hukum tidak ada perbedaan mekenisme yang harus ditempuh untuk proses PHK antara pekerja dan pengusaha. Keduanya tetep harus merunjuk pada Undang-Undang No. 13 Tahun 2003 Tentang Ketenagakerjaan dan Undang-Undang No. 2 Tahun 2004 Tentang Penyelesaian Perselishan Hubungan Industrial jika ingin memutuskan hubungan kerja.

Berdasarkan hasil wawancara penulis dengan ibu Hening Wahyuningtyas,S.H.,M.M seorang PLH. PANMUD di Pengadilan Hubungan Industrial Semarang terkait mekanisme PHK berdasarkan Undang-Undang No. 13 Tahun 2003 Tentang Ketenagakerjaan pada Hari Rabu, 18 Maret 2015 Pukul 10.25 WIB, menyatakan bahwa :

"Undang-Undang PPHI mengatur langkahlangkah yang harus ditempuh untuk proses PHK sebagai berikut :

1. Perundingan secara bipartit antara pengusaha dangan pekerja atau serikat pekerja. Jika dalam tahap ini pihak sepakat memutuskan hubungan kerja berikut dengan hak dan kewajibannya, maka tidak ada masalah

2. Apabila perundingan bipartite seperti dijalaskan pada poin 1 menemui jalan buntu, maka para pihak mencatatkan perselisihan itu ke instansi ketenagakerjaan setempat. Nantinya, pegawai instansi itu akan menawarkan pekerja dan pengusaha untuk memilih proses mediasi atau konsiliasi. Jika proses mediasi dan konsiliasi itu membuahkan kesepakatan, maka kesepakatan itu dituangkan dalam sebuah perjanjian bersama. Perjanjian itu harus didaftarkan ke Pengadilan Hubungan Industrial (PHI). Apabila di kemudian hari ada pihak yang melanggar perjanjian bersama, maka pihak yang merasa dirugikan bisa langsung memohonkan eksekusi ke PIH.

3. Jika proses mediasi atau konsiliasi masih juga mentok, para pihak 
bisa membawakan perselisihan PHK itu ke PHI bisa langsung mengajukan ke kasasi ke Mahkamah Agung."

Yang menjadi kendala secara teknis yaitu apabila para pihak tidak hadir dalam di persidangan. Tetapi persoalan tersebut bisa diatasi pleh pihak Pengadilan Hubungan Industrial. Disini yang paling fursial adalah untuk perkara prodeo kalau tidak ada biayanya atau gratis, menganai pelaksanaan putusan akhirnya atau eksekusinya terkendala dengan biaya. Karena anggaran dari pemerintah terbatas.

Satu hal lain yang diperkenalkan oleh Pengadilan Hubungan Industrial adalah dalam berperkara di Pengadilan Hubungan Industrial, pihak-pihak yang berperkara dengan nilai gugatan dibawah Rp. 150.000.000,- (seratus lima puluh juta rupiah) tidak dikenakan biaya perkara termasuk biaya eksekusi.

Secara normatif ditegaskan bahwa Undang-Undang Nomor 2 Tahun 2004 Tentang Penyelesaian Perselisihan Hubungan Industrial dibentuk dalam rangka mewujudkan hubungan industrial yang harmonis, dinamis dan berkeadilan serta menyikapi perkembangan industrialisasi yang mengakibatkan semakin meningkat dan kompleks perselisihan hubungan industrial.

Pada asas berperkara di Pengadilan Hubungan Industrial tidak jauh berbeda dalam berperkara perdata di lingkungan peradilan umum pada umumnya, karena hukum yang dipakai oleh Pengadilan Hubungan Industrial adalah hukum acara perdata yang berkalu di lingkungan peradilan umum kecuali yang diatur secara khusus dalam Undang-Undang Nomor 2 Tahun 2004 Tentang Penyelesaian Perselisihan Hubungan Industrial

Berdasarkan hasil wawancara penulis dengan Daryono, seorang Hakim Ad-Hoc di Pengadilan Hubungan Industrial Semarang, terkait Pemenuhan Hak Pekerja/Buruh Yang Mengalami PHK pada Hari Rabu, 18 Maret 2015 Pukul 09.15 WIB, menyatakan bahwa :

“Undang-Undang Nomor 2 Tahun 2004 tentang PPHI merupakan lek spesialis dari hukum acara perdata. Jadi selama HIR/RBG tidak mengatur dan selama di dalam Undang-Undang
Nomor 2 tahun 2004 tentang PPHI sudah di atur hukum acaranya maka HIR tidak dipakai. Tetepi kalau dalam Undang-Undang Nomor 2 tahun 2004 tentang PPHI tenyata tidak diatur maka menggunakan HIR."

Proses PHI mengacu pada "UndangUndang Nomor 2 Tahun 2004 tentang PPHI, jika ada hal yang tidak mengacu kepada Undang-Undang PPHI teknis terkait pemenuhan hak pekerja akan terjadi permasalahan perselisihan hubungan industrial. Menurut Daryono, "dalam hal pemanggilan para pihak gugatan masuk setelah gugatan masuk otomatis ketua pengadilan menetapkan majelis hakim yang berwenang untuk mengadili perkara tersebut. Setelah ditetapkan majelis hakim, maka dipanggil para pihak yang bersengketa yaitu para pengugat dan tergugat" (Wawancara, 18 Maret 2015, di Pengadilan Hubungan Industrial Semarang).

Teknis tersebut digunakan HIR tidak menggunakan Undang-Undang Nomor 2 Tahun 2004 tentang PPHI, karena tidak ada mekanismenya untuk memanggil para pihak. Proses persidangan, sudah diatur dari guguatan, sampai putusan. Yang belum diatur menganai eksekusi tidak diatur oleh UndangUndang Nomor 2 Tahun 2004 tentang PPHI sehingga mengacu pada HIR .

Daryono juga mengutarakan bahwa kelemahannya adalah dengan mengacu kepada HIR kita kembali kepada UU colonial. Dan membutuhkan waktu yang lebih lama, padahal filosofinya UU PPHI adalah mempersingkat proses. Karena di Penggadilan dibatasi 50 hari kerja, di MA dibatasi 30 hari kerja.Yang tidak diatur oleh PPHI adalah pemanggilan tergugat/penggugat (Wawancara, Rabu, 18 Maret 2015, di Pengadilan Hubungan Industrial Semarang).

Apabila PHK tidak dapat dihindari, maka sesuai alasan yang mendasari terjadinya PHK maka pengusaha wajib membayar uang pesangon dan uang penghargaan masa kerja yang disesuaikan dengan masa kerja serta uang penggantian hak. Dalam Pasal 156 ayat (1) Undang-Undang Nomor 13 Tahun 2003 menyebutkan bahwa "Dalam hal terjadi pemutusan hubunga kerja dan uang penggantian hak yang seharusnya diterima. 
Berdasarkan hasil wawancara penulis Hening Wahyuningtyas, seorang panitera muda di Pengadilan Hubungan Industrial Semarang, terkait pemenuhan hak pekerja/ buruh yang mengalami PHK berdasarkan Undang-Undang No. 2 Tahun 2004 Tentang Penyelesaian Perselisihan Hubungan Industrial, kita bisa mendapatkan informasi bahwa pemenuhan hak pekerja/buruh harus sesuai dengan masa kerja, sedangkan dalam Undang-Undang No. 2 Tahun 2004 Tentang Penyelesaian Perselisihan Hubungan Industrial merupakan teknis pelaksanaan sidang. Pemenuhan hak pekerja/buruh diatur dalam Undang-Undang Nomor 13 Tahun 2003 tentang Ketenagakerjaan Pasal 156 (Wawancara, 18 Maret 2015).

Terkait pemenuhan hak pekerja/buruh dalalm lingkup pengadilan Hubungan Industrial terkadang tidak sesuai dengan Undang-Undang No. 2 Tahun 2004 Tentang Penyelesaian Perselisihan Hubungan Industrial karena PPHI tidak mengatur secara keseluruhan hukum acaranya, sehingga proses tersebut tidak sesuai dengan harapan buruh karena Undang-Undang No. 2 Tahun 2004 Tentang Penyelesaian Perselisihan Hubungan Industrial tidak mengatur termasuk proses eksekusi.

\section{Perlindungan Hukum Terhadap Hak Peker- ja/Buruh Terkait Pelaksanaan Pemberian Kompensasi Terhadap Pekerja/Buruh}

PHK adalah masalah sehari-hari yang seringkali terjadi di sekeliling masyarakat. Dalam berbagai kasus,PHK menjadi penyulut konflik hubungan industrial antara kaum pekerja/buruh dan pengusaha. Konflik di seputar PHK tersebut seringkali berawal dari kurangnya pemahaman dari kedua belah pihak mengenai mekanisme pengambilan keputusan yang fairbagi kepentingan masing-masing. Konflik antara pekerja/buruh dan pengusaha biasanya terpusat pada aspek normatif seperti besarnya uang pesangon yang layak, uang penghargaan masa kerja dan ganti rugi yang kesemuanya merupakan bagian dari komponen upah yang riil.

PHK selalu memiliki akibat hukum, baik terhadap pengusaha maupun terhadap pekerja/buruh itu sendiri. Akibat hukum dimaksud adalah bentuk pemberian kompensasi upah kepada pekerja/buruh yang hubungan kerjanya terputus dengan pengusaha. Bagi pengusaha, ada kewajiban untuk memberikan kompensasi upah kepada pekerja/ buruh yang diputuskan hubungan kerjanya, sebaliknya pekerja/buruh berhak untuk mendapatkan kompensasi upah yang dimaksud. Namun demikian, tidak selamanya PHK selalu diikuti dengan pemberian kompensasi upah kepada pekerja/buruh. Adakalanya pekerja/buruh tidak mendapatkan kompensasi apapun atas terputusnya hubungan kerja dengan pengusaha, misalnya pekerja/buruh yang hubungan kerjanya diakhiri dalam masapercobaan atau hubungan kerjanya didasarkan pada PKWT.

Menurut Daryono, Hakim Ad-Hoc di Pengadilan Hubungan Industrial Semarang, perlindungan hukum terkait pelaksanaan pemberian kompensasi terhadap pekerja/buruh dinyatakan bahwa:

"Terkait perlindungan berdasarkan UndangUndang Nomor 13 Tahun 2003 tentang Ketenagakerjaan minimal harus sesuai, yang diputus oleh hakim, dilihat dari peristiwa saat persidangan, lalu ditarik ke normanya. Apakah ada perjanjian kerja yang bersifat privat/public, privatnya adalah perjanjian kerja karena para pihak yang mengikatkan diri.Sedangkan bersifat publiknya karena berlaku untuk semua. Tidak semua pekerja mempunyai itikat baik dalam bekerja, tetapi adajuga pekerja yang mempunyai niat buruk atau ingin mencari kesalahan perusahaan.Jadi dapat dilihat dari fakta-fakta saat persidangan terungkap. Di situ akan terbaca dari keterangan saksi" (Wawancara, 18 Maret 2015, di Pengadilan Hubungan Industrial Semarang).

Penyelesaian perselisihan hubungan industrial dapat diwujudkan bila didukung oleh sistem mekanisme yang baik, yaitu bila kebenaran normatif dan kebenaran empiris telah dapat diwujudkan dalam sistem hukum ketenagakerjaan. Nyatanya keadilan dalam penyelesaian ini dihadapkan banyak kendala, penyebab sulitnya mewujudkan perlin- 
dungan terhadap pekerja.

Secara umum persoalan perburuhan lebih banyak di identikan dengan perosalan antara pekerja dengan pengusaha.Pemahaman demikian juga dipahami sebagian besar para pemgambil kebijakan perburuhan sehingga terjadi redukksi pemahaman terhadap buruh sebagai pekerja dan buruh sebagai suatu profesi dan kategori sosial.Pemahaman tersebut mengakibatkan perlindungan terhadap pekerja/buruh menjadi sangat lemah.

Sebagaimana yang dinyatakan oleh Daryono, putusan hakim harus sesuai dengan Undang-Undang Nomor 13 Tahun 2003 tentang Ketenagakerjaan.Putusan pengadilan tersebut berisi menganai apakah bagi pihak penggugat merasa adil, adil tidak berarti bagi yang kalah selalu merasa tidak adil.Sesuatu yang terungkap di persidangan, peran hakim bersifat pasif dan para pihak yang bercerita dan memberikan keterangan.Putusan pengadilan harus bersifat adil karena mereka samasama membutuhkan, dua pihak yang bertentangan sama-sama membutuhkan sehingga kepastian hukum pekerja/buruh merasa terlindungi secara hokum (Wawancara, $18 \mathrm{Ma}-$ ret 2015, di Pengadilan Hubungan Industrial Semarang).

Hasil wawancara yang penulis lakukan di Pengadilan Hubungan Industrial Semarang menunjukkan bahwa berdasarkan filosofis Undang-Undang PHI, pengadilan ini dibentuk dengan tujuan menciptakan mekanisme yang cepat, tepat, dan adil bagi buruh. Cepat karena dalam tahap Pengadilan Hubungan Industrial, majelis hakim harus memutus perkara dalam waktu 50 hari kerja dan jika salah satu pihak mengajukan kasasi maka majelis hakim wajib memutus perkara dalam jangka waktu 30 hari kerja sejak pendaftaran kasasi.

\section{Pemenuhan Hak Pekerja/Buruh Yang Mengalami PHK di Pengadilan Hubungan Industrial.}

Berdasarkan Undang-Undang Nomor 2 tahun 2004 tentang penyelesaian perselisihan hubungan indutrial mengatur langkahlangkah yang harus ditempuh untuk proses PHK sebagai berikut. Pertama, perundingan secara bipartit antara perusahaan dengan pe- kerja atau serikat pekerja. Jika dalam tahap ini kedua belah pihak sepakat memutuskan hubungan kerja berikut dengan hak dan kewajiban, maka tidak akan terjadi masalah. Kedua, apabila perundingan bipartit seperti dijelaskan pada poin 1 memenui jalan buntu, maka para pihak mencatatkan perselisihan ini ke instansi ketenagakierjaan setempat. Dan nantinya pegawai di instansi akan menawarkan pekerja dan pengusaha untuk memilih proses mediasi atau konsiliasi. Jika proses mediasi atau konsiliasi itu membuahkan kesepakatan maka kesepakatan itu dituangakan dalam sebuah perjanjian bersama. Perjanjian harus didaftarkan ke Pengadilan Hubungan Industrial (PHI). Apabila ada pihak yang melanggar sebuah perjanjian, maka pihak yang merasa dirugikan bisa langsung memohonkan eksekusi ke Pengadilan Hubungan Industrial (PHI). Ketiga, kalau proses mediasi atau konsiliasi masih juga mentok, para pihak dapat membawa perselisihan PHK itu ke Pengadilan Hubungan Industrial (PHI) untuk diputuskan. Nantinya, pihak yang mersa tidak puas dengan putusan PHI bisa langsung mengajukan ke kasasi ke Mahkamah Agung.

Persyaratan lain yang harus dipenuhi pengusaha dalam melakukan pemutusan hubungan kerja adalah harus adanya bukti pendukung antara lain pekerja/buruh tertangkap tangan, ada pengakuan dari pekerja/buruh yang bersangkutan, atau bukti lain berupa laporan kejadian yang dibuat oleh pihak yang berwenan di perusahaan yang bersangkutan dan didukung sekurang-kurangnya 2 (dua) orang saksi.

Mengenai pemenuhan hak pekerja/buruh yang mengalami PHK diatur dalam Pasal 2 Undang-Undang Nomor 2 Tahun 2004 tentang Penyelesaian Perselishan Hubungan Industrial, dimana Pasal tersebut berisi perselisihan hak, perselisihan kepentingan, perselisihan pemutusan hubungan kerja, dan perselisihan antar serikat pekerja/serikat buruh hanya dalam satu perusahaan.

Dari keempat jenis perselisihan yang terjadi adalah perselisihan PHK. Faktor yang menjadi penyebab terjadinya pemutusan hubungan kerja yang sering terjadi disini karena berbagai sebab. Pertama, faktor penyebab PHK oleh Perusahaan. Pada umumnya ke- 
langsungan ikatan kerja bersama antara pengusaha dengan tenaga kerja terjalin apabila kedua belah pihak masih saling membutuhkan dan saling patuh atau taat akan perjanjian yang telah disepakati pada saat mereka mulai menjalani kerja bersama. Dengan adanya keterikatan bersama antara para tenaga kerja berarti masing-masing pihak memiliki hak dan kewajiban. Demikian pula sebaliknya, apabila terjadi PHK berarti manajer tenaga kerja dituntut untuk memenuhi hak dan kewajiban terhadap tenaga kerja sesuai dengan kondisi pada saat terjadi kontrak kerja.

Bagi setiap pekerja/buruh PHK bisa jadi sebuah mimpi buruk. Setiap pekerja/ buruh sedapat mungkin mengupayakan agar dirinya tidak sampai kehilangan pekerjaan. PHK dapat berarti awal dari sebuah penderitaan. Namun demikian, suka atau tidak suka, pengakhiran hubungan kerja sesungguhnya adalah sesuatu yang cukup dekat dan sangat mungkin serta wajar terjadi dalam konteks hubungan kerja, hubungan antara pengusaha dengan pekerja/buruh.

Secara yuridis dalam Undang-Undang Nomor 13 Tahun 2003 tentang Ketenagakerjaan, PHK perusahaan disebabkan karena perusahaan mengalami kemunduruan sehingga perlu rasionalisasi atau pengurangan jumlah pekerja/buruh. Dalam Undang-Undang Nomor 13 Tahun 2003 Pasal 151 ayat (1) ditentukan bahwa pengusaha, pekerja/buruh, serikat pekerja/serikat buruh, dan pemerintah, dengan segala upaya harus mengusahakan agar jangan terjadi pemutusan hubungan kerja. Dalam hal segala upaya telah dilakukan, tetapi pemutusan hubungan kerja tidak dapat dihindari, maka maksud pemutusan hubungan kerja wajib dirundingkan oleh pengusaha dan serikat pekerja/serikat buruh atau dengan pekerja/buruh apabila pekerja/buruh yang bersangkutan tidak menjadi anggota serikat pekerja/serikat buruh. Menurut UU tersebut, PHK juga disebabkan karena pekerja/ buruh telah melakukan kesalahan, baik kesalahan yang melanggar ketentuan yang tercantum dalam peraturan perusahaan, perjanjian kerja atau PKB (kesalahan ringan), maupun kesalahan pidana (kesalahan berat). Pekerja/ buruh yang diputus hubungan kerjanya karena alasan telah melakukan kesalahan berat hanya dapat memperoleh uang penggantian hak.

Kedua, selain faktor perusahaan, faktor penyebab PHK juga bisa berasal dari pekerja/ buruh. Pekerja/buruh berhak untuk memutuskan hubungan kerja dengan pihak pengusaha, karena pada prinsipnya pekerja/buruh tidak boleh dipaksakan untuk terus menerus bekerja bilamana ia sendiri tidak menghendakinya. Dengan demikian PHK oleh pekerja/buruh ini, yang aktif untuk meminta diputuskan hubungan kerjanya adalah pekerja/ buruh tersebut.

Pekerja/buruh dapat mengajukan permohonan PHK kepada lembaga PPHI dalam hal pengusaha melakukan perbuatan sebagai berikut: 1) menganiaya, menghina secara kasar atau mengancam pekerja/buruh; 2) membujuk atau menyuruh pekerja/buruh untuk melakukan perbuatan yang bertentangan dengan peraturan perundang-undangan; 3) tidak membayar upah tepat waktu yang telah ditentukan selama 3 (tiga) bulan berturutturut atau lebih; 4) tidak melakukan kewajiban yang telah dijanjikan kepada pekerja/ buruh; 5) memerintahkan pekerja/buruh untuk melaksanakan pekerjaan diluar yang diperjanjikan; dan 6) memberikan pekerjaan yang membahayakan jiwa, keselamatan, kesehatan atau kesusilaan pekerja/buruh, sedangkan pekerja tersenut tidak dicantumkan pada perjanjian kerja (Lalu Husni, 2003, hlm. 186).

Pekerja/buruh dapat mengahiri hubungan kerja dengan melakukan pengunduran diri atas kemauan sendiri tampa perlu meminta penetapan dari lembaga PPHI, dan kepada pekerja/buruh yang bersangkutan memperoleh uang penggantian hak sesuai Pasal 156 Ayat 4 Undang-Undang Nomor 13 Tahun 2003. Selain uang penggantian hak, pekerja/buruh dberikan uang pisah yang besar dan pelaksanaanya diatur dalam perjanjian kerja, peraturan perusahaan atau PKB.

Selain PHK oleh pengusaha dan pekerja/buruh, hubungan kerja juga dapat atau berakhir demi hukum, artinya hubungan kerja tersebut harus diputus dengan sendirinya. Pekerja/buruh tidak perlu mendapatkan penetapan PHK dari lembaga yang berwanang. 
Analisis Faktor-faktor Pemutusan Hubungan Kerja Berdasarkan Putusan Hakim Pengadilan Hubungan Industrial

PHK merupakan awal dari seseorang pekerja/buruh dari berakhirnya mempunyai pekerjaan ataupun pemula dari berakhirnya kemampuan presentasi untuk membiayai keperluan hidup sehari-hari bagi diri sendiri dan keluargannya. Jika setiap orang berhak atas pekerjaan, orang tersebut setelah mendapat pekerjaan harus berhak pula terus bekerja, artinya tidak diputuskan hubungan kerjannya, pada esok harinya setelah ia mendapat pekerjaan. Oleh karena itu seharusnya tidak ada pemberhentian pekerja/buruh sama sekali. Akan tetapi, kenyataan sehari-hari membuktikan bahwa PHK tidak mungkin dapat dicegah seluruhnya.

Ada beberapa alasan dan kondisi tertentu menyebabkan dapat berakhirnya putusnya hubungan kerja, baik yang terletak pada diri pekerja/buruh maupun pengusaha. PHK yang didasarkan pada alasan yang terletak pada diri pekerja/buruh adalah bahwa PHK dimaksud dikehendaki oleh pengusaha karena terdapat peristiwa hukum yang dilakukan atau melibatkan pekerja/buruh, dimana peristiwa hukum yang dilakukan atau melibatkan pekerja tersebut dapat berakibat diakhirinya hubungan kerja. Peristiwa hukum tersebut bisa dalam bentuk pelanggaran pekerja/buruh terhadap ketentuan perundangundangan, peraturan perusahaanatau PKB yang didalamnya secara tegas menyebutkan bahwa pelanggaran dapat berakibat putusnya hubungan kerja antara pekerja/buruh dengan pengusaha.

Apabila ditelaah dari putusan hakim mengenai PHK, maka ada beberapa penyebab terjadinya PHK. Pertama, PHK secara lisan oleh pengusaha. Alasan PHK ini terdapat pada perkara antara sdri: Muchid, Mukdi, Rakimah, Ratiyah melawan PT. HIJO MAS dengan Nomor Perkara 09/G/2010/ PHI.SMG, tanggal 10 Mei 2010. PHK dilakukan oleh PT. HIJO MAS (TERGUGAT) terhadap sdri : Muchid, Mukdi, Rakimah, Ratiyah (PENGGUGAT) dikarenakan pemberian Uang Pesangon tidak sesuai dengan UMR. Penggugat melakukan PHK secara lisan den- gan alasan perusahaan mengalamin sepi order. Penggugat menyatakan bahwa tergugat adalah pekerja borongan yang bekerja pada seorang mandor dan tidak mempunyai daftar abesensi hadir di Perusahaan dan Terggugat menganggap para Penggugat adalah pekerja harian lepas. Pada tanggal 3 Oktober 2009 penggugat melakukan PHK karena alasan efisiensi. Dan Tergugat harus membayar hakhak para Penggugat berdasarkan Pasal 164 ayat (3) Undang-Undang Nomor 13 Tahun 2003.

Kedua, efisiensi yang dilakukan oleh peusahaan. Penyebab terjadinya PHK ini dalam Perkara antara Djoko Pramono (PENGGUGAT) melawan PT. SUWATAMA (TERGUGAT) dengan Nomor Perkara 38/G/2011/ PHI.SMG, Tanggal 3 Febuari 2012. Pemutusan hubungan kerja yang dilakukan Tergugat, juga adanya skrosing sebagaimana diatur dalam Pasal 155 ayat (3) Undang-Undang Nomor 13 Tahun 2003 tentang Ketenagakerjaan sehingga upah Penggugat tidak dibayarkan lagi oleh Tegugat. Atas perbuatan Tergugat tersebut, Penggugat saat ini tidak menghasilkan uang (pangangguran) sementara kebutuhan hidup keluarga terus mendesak ditambah kondisikesehatan Penggugat yang tidak menentu akibat riwayat penyakit jantungnya.

Ketiga, adanya kesalahan berat yang dilakukan oleh pekerja/buruh. Yang menjadi alasan penyebab terjadinya PHK tersebut terdapat dalam perkara sdr. Ani Mariani (PENGGUGAT) Melawan PT. LINGGARJATI MULIA ABADI (TERGUGAT) dengan Nomor Perkara 14/Pdt.Sus-PHI/G/2014/PN.SMG tanggal 2 Juni 2014. Alasan pemutusan hubungan kerja karena dinilai secara keseluruhan merupakan pelanggaran berat karena telah merugikan perusahaan sebesar lebih dari US \$500 akibat dari berbagai kesalahan Penggugat. Dimana waktu perusahaan menagih ke buyer dan buyer tidak mau membayar karena kesalahan dari Penggugat dimana kurang cermat terhadap tanggugjawab yang diberikan perusahaan ke Penggugat.

\section{Putusan Menganai Perselisihan PHK Di Pengadilan Hubungan Industrial}

Apabila melihat dari putusan-putusan 
hakim PHI pada PN Semarang terhadap kasus-kasus PHK, bahwa pada umumnya komponen kompensasi yang diputuskan oleh hakim tetap berdasarkan Pasal 156 UndangUndang Nomor 13 Tahun 2003 Tentang Ketenagakerjaan, yang meliputi uang pesangon, uang penghargaan masa kerja dan uang penggantian hak. Akan tetapi, uang penggantian hak disini, hakim menentukan dengan uang penggantian hak perumahan dan perobatan sebesar 15\% dari uang pesangon dan/ atau uang penghargaan masa kerja. Dalam beberapa putusan hakim juga menambahkan kekurangan-kekurangan upah dari pekerja yang dipangkas oleh majikan.

Sesuai dengan ketentuan Permen Nomor 01/MEN/1999 jo. Kepmen Nomor 226/ MEN/2000 tentang upah minimum dan Undang-Undang Nomor 13 Tahun 2003 Tentang Ketenagakerjaan dinyatakan bahwa setiap tahun pemerintah dalam hal ini Pemerintah Provinsi menetapkan UMP dengan tujuan kesejahteraan atau upah yang diterima pekerja/buruh tidak merosot atau lebih rendah dari perkembangan harga-harga di pasar dan inflasi atau dengan kata lain, upah yang diterima pekerja/buruh sesuai dengan Kebutuhan Hiduip Minimum (KHM) seorang pekerja/buruh.

Berdasarkan Permen Nomor 01/ MEN/1999 dinyatakan bahwa UMP hanya berlaku bagi seseorang pekerja/buruh dengan masa kerja kurang dari 1 (satu) tahun, sedangkan dengan masa kerja lebih dari 1 (satu) tahun, besarnya dirundingkan secara bpartit antara pengusaha dengan SP/SB untuk disepakati dan sebagai standar untuk menetapkan upah yang dihasilnya dimuat dalam perjanjian kerja, peraturan perusahaan, dan PKB. Bagi pengusaha yang belum berdiri SP/ $\mathrm{SB}$, diharapkan supaya pekerja membentuk tim 5-10 orang wakil para pekerja untuk berunding dengan pihak pengusaha den sesuai prinsip hubungan industrial, pengusaha sebagai mira pekerja harus secara terbuka menerima permintaan pekerja untuk berunding.

Pemberian kompensasi sebagai akibat dari berakhirnya hubungan kerja, dipengaruhi oleh masa kerja pekerja/buruh yang di PHK. Menurut ketentuan Pasal 156 Ayat (1) Undang-Undang Nomor 13 Tahun 2003 ten- tang Ketenagakerjaan, dasar penetapannya adalah sebagai berikut: a) Masa kerja kurang dari 1 (satu) tahun mendapatkan uang pesangon, 1 (satu) bulan upah; b) Masa kerja 1 (satu) tahun atau lebih tetapi kurang dari 2 (dua) tahun, mendapatkan uang pesangon sebesar 2 (dua) bulan upah; c) Masa kerja 2 (dua) tahun atau lebih tetapi kurang dari 3 (tiga) tahun, mendapatkan uang pesangon sebesar 3 (tiga) bulan upah; d) Masa kerja 3 (tiga) tahun atau lebih tetapi kurang dari 4 (empat) tahun, mendapatkan uang pesangon sebesar 4 (empat) bulan upah; e) Masa kerja 4 (empat) tahun atau lebih tetapi kurang dari 5 (lima) tahun, mendapatkan uang pesangon sebesar 5 (lima) bulan upah; f) Masa kerja 5 (lima) tahun atau lebih, tetapi kurang dari 6 (enam) tahun, mendapatkan uang pesangon sebesar 6 (enam) bulan upah; g) Masa kerja 6 (enam) tahun atau lebih tetapi kurang dari 7 (tujuh) tahun, 7 (tujuh) bulan upah; h) Masa kerja 7 (tujuh) tahun atau lebih tetapi kurang dari 8 (delapan) tahun, mendapatkan uang pesangon sebesar 8 (delapan) bulan upah; i) Masa kerja 8 (delapan) tahun atau lebih, mendapatkan uang pesangon sebesar 9 (sembilan) bulan upah.

Untuk perhitungan uang penghargaan masa kerja sebagaimana dimaksud pada Pasal 156 ayat (2) ditetapkan sebagai berikut: a) Masa kerja 3 (tiga) tahun atau lebih tetapi kurang dari 6 (enam) tahun, mendapatkan uang penghargaan kerja sebesar 2 (dua) bulan upah; b) Masa kerja 6 (enam) tahun atau lebih tetapi kurang dari 9 (sembilan) tahun, mendapatkan uang penghargaan kerja sebesar 3 (tiga) bulan upah; c) Masa kerja 9 (sembilan) tahun atau lebih tetapi kurang dari 12 (duabelas) tahun, mendapatkan uang penghargaan kerja sebesar 4 (empat) bulan upah; d) Masa kerja 12 (duabelas) tahun atau lebih tetapi kurang dari 15 (lima belas) tahun, mendapatkan uang penghargaan kerja sebesar 5 (lima) bulan upah; e) Masa kerja 15 (lima belas) tahun atau lebih tetapi kurang dari 18 (delapan belas) tahun, mendapatkan uang penghargaan kerja sebesar 6 (enam) bulan upah; f) Masa kerja 18 (delapan belas) tahun atau lebih tetapi kurang dari 21 (duapuluh satu) tahun, mendapatkan uang penghargaan kerja sebesar 7 (tujuh) bulan upah; 
g) Masa kerja 21 (duapuluh satu) tahun atau lebih tetapi kurang dari 24 (duapuluh empat) tahun, mendapatkan uang penghargaan kerja sebesar 8 (delapan) bulan upah; dan h) Masa kerja 24 (duapuluh empat) tahun atau lebih, mendapatkan uang penghargaan kerja sebesar 10 (sepuluh) bulan upah.

Untuk uang penggantian hak yang seharusnya diterima sebagaimana dimaksud dalam Pasal 156 Ayat (4), dengan ketentuan sebagai berikut: 1) Cuti tahunan yang belum diambil dan belum gugur; 2) Biaya atau ongkos pulang untuk pekerja/buruh dan keluarganya ketempat dimana pekerja/buruh diterima bekerja; 3) Penggantian perumahan serta pengobatan dan perawatan ditetapkan 15\% (limabelas perseratus) dari uang pesangon dan atau uang penghargaan masa kerja bagi yang memenuhi syarat; 4) Hal-hal lain yang ditetapkan dalam perjanjian kerja, peraturan perusahaan atau perjanjian kerja bersama.

Berdasarkan ketentuan Undang-Undang Nomor 13 Tahun 2003, pemberian kompensasi bagi pekerja/buruh yang hubungan kerjanya terputus dengan pengusaha diatur dengan memperhatikan alasan-alasan PHK, baik alasan yang terletak pada diri pekerja/ bueuh atau yag terletak pada diri perusahaan itu sendiri.

Terhadap putusan-putusan $\mathrm{PHI}$ pada PN Semarang terhapad kasus-kasus PHK yang dibahas dalam skripsi ini, maka hakim menggunakan dasar perhitungan kompensasi sesuai dengan yang diatur oleh UndangUndang dengan mengacu pada Pasal 156 Undang-Undang Nomor 13 Tahun 2003.

\section{Dasar Pertimbangan Hakim Dalam Mem- berikan Kompensasi Kepada Pekerja/Bu- ruh}

PHK adalah masalah sehari-hari yang seringkali terjadi di sekeliling masyarakat. Dalam berbagai kasus, PHK menjadi permasalahan hubungan industrial antara kaum pekerja/buruh dan pengusaha. Permasalahan PHK tersebut seringkali berawal dari kurangnya pemahaman kedua belah pihak menganai mekanisme pengambilan keputusan yang fair bagi kepentingan masing-masing. Permasalahan tersebut terpusat pada aspek normatif seperti besarnya uang pesangon yang layak, uang penghargaan masa kerja dan uang ganti rugi yang merupakan bagian dari komponen upah yang riil.

PHK selalu memiliki akibat hukum, baik terhadap pengusaha maupun terhadap pekerja/buruh itu sendiri. Akibat hukum yang dimaksud adalah bentuk pemberian kompensasi upah kepada pekerja/buruh yang hubungan kerjanya terputus dengan pengusaha. Bagi pengusaha merupakan kewajiban untuk memberikan kompensasi upah kepada pekerja/buruh yag diputuskan hubungan kerjanya, sebaiknya pekerja/buruh berhak untuk mendapatkan kompensasi upah tersebut. Dengan demikian, tidak selamanya PHK selalu diikuti dengan pemberian kompensasi upah kepada pekerja/buruh. Adakalanya pekerja/buruh tidak mendapatkan kompensasi apapun atas terputusnya hubungan kerja dengan pengusaha, misalnya pekerja/buruh yang hubungan kerjanya diakhiri dalam masa percobaan atau hubungan kerja didasarkan pada PKWT.

Apabila permasalahan PHK ini sampai ke pengadilan, maka pengadilan tidak boleh menolak, memeriksa, mengadili dan memutus perkara yang diajukan dengan dalil bahwa hukum tidak ada/kurang jelas (berdasarkan Pasal 16 Undang-Undang Nomor 2 Tahun 2004 tentang PPHI). Hakim berkewajiban untuk mengadili, mengikuti dan memahami nilai-nilai hukum dan rasa keadila yang hidup dalam masyarakat (berdasarkan Pasal 28 Undang-Undang Nomor 2 Tahun 2004 tentang PPHI).

Pertimbangan hakim adalah pertimbangan hukum yang merupakan jiwa dan intisari putusan. Pertimbangan berisi analisi, agumnetasi, pendapat atau kesimpulan hukum dari hakim yang memeriksa perkara. Kemudian diikuti analisi, hukum apa yang diterapkan untuk menyelesaiakan perkara tersebut.

Melihat dari putusan-putusan yang dianalisi dalam skripsi ini, maka kompensasi upah yang harus diberikan pengusaha kepada pekerja/buruh akibat terjadinya $\mathrm{PHK}$, hakim berusaha bertindak adil dalam pertimbangan-pertimbangan yang dituangkan dalam pokok perkara, sehingga dapat mencapai 
dasar penyelesaian sengketa. Adapun yang menjadi dasar pertimbangan hakim tersebut antara lain sebagai berikut.

Pertama, adanya perbuatan melawan hukum, dalam Perkara Nomor 09/G/2010/ PHI.SMG, bahwa yang terjadi adalah PHK secara lisan dengan alasan perusahaan sedang mengalami sepi pekerjaan/sepi order. Sebelumnya pada Penggugat maupun Tergugat tidak mentandatangani surat perjanjian kerja dikarenakan melamar pekerjaan di tempat Penggugat secara lisan. Perjanjian kerja lisan diperbolehkan seperti yang tercantum dalam Pasal 51 Ayat (1) Undang-Undang No. 13 Tahun 2003 yang berbunyi "Perjanjian kerja dibuat secara tertulis atau lisan". Sehingga dasar hukum yang dipergunakan dalam perkara a quo adalah berdasarkan Pasal 164 Ayat (3) Undang-Undang No. 13 Tahun 2003 sehingga para Penggugat berhak atas kompensasi pesangon dan masa kerja para Penggugat pun dihitung hanya sampai dengan Tanggal 3 Oktober 2009. Upah yang diberikan tersebut masih dibawah UMK Semarang Tahun 2009 sebesar Rp. 838.500,- bahwa berdasarkan Pasal 90 Ayat (1) Undang-Undang No. 13 Tahun 2003: "Pengusaha dilarang mebayar upah lebih rendah dari upah minimum".

Kedua, penggugat telah mekakukan perbuatan melawan hukun dengan alasan efisiensi dalam Perkara No.38/G/2011/PHI. SMG, bahwa telah terjadi PHK yang dilakukan Tergugat bukan dikarenakan Penggugat telah melakukan tindakan indisipliner tetapi PHK yang dipaksakan dan diada-adakan atau perusahaan ingin mengefisiensi karyawan, dimana dalam hal ini Penggugat berhak mendapatkan pesangon sesuai ketentuan Undang-Undang No. 13 Tahun 2003 Pasal 164 Ayat (3) yang berbunyi :"Pengusaha dapat melakukan pemutusan hubungan kerja terhadap pekerja/buruh karena perusahaan tutup bukan karena mengalami kerugian 2 (dua) tahun berturut-turut atau bukan karena keadaan memaksa (force majeur) tetapi perusahaan melakukan efisiensi, dengan ketentuan pekerja/buruh berhak atas uang pesangon sebesar 2 (dua) kali ketentuan Pasal 156 ayat (2), uang penghargaan masa kerja sebesar 1 (satu) kali ketentuan Pasal 156 ayat (3) dan uang penggantian hak sesuai sesuai ketentuan Pasal 156 ayat (4)". Sehingga dasar hukum yang dipergunakan dalam perkara ini Hakim menyatakan bahwa gugatan Penggugat adalah Prematur atau Nebis In idem atau kabur (abscuurliber), oleh karena itu gugatan harus dinyatakan tidak dapat diterima (Niet Ontvankelijke Verklaard).

Ketiga, penggugat telah melakukan perbuatan melawan hukum dengan alasan karena telah merugikan perusahaan dalam Perkara No. 14/Pdt.Sus-PHI/G/2014/ PN.SMG, bahwa telah terjadi PHK dengan alasan kesalahan berat karena telah merugikan perusahaan sebesar $\$ 500$ atau sekitar Rp. 200.000.000,- akibat dari berbagai kesalahan Penggugat. Sehingga dasar hukum yang dipergunakan dalam perkara ini Hakim menyatakan bahwa PHK dalam perkara a quo yang terjadi sejak 26 Desember 2013 dan dikualifikasikan PHK karena pekerja melakukan kesalahan. Hak-hak yang diperoleh para Penggugat diatur dalam Pasal 161 Ayat (3) serta komponen untuk perhitungan uang pesangon adalah masa kerja dan upah dan segala macam tunjangan yang bersifat tetap sepeti yang diatur dalam Pasal 157 UndangUndang Nomor 13 Tahun 2003 tentang Ketenagakerjaan.

\section{Analisis Kepastian Hukum dalam Putusan Hakim Pengadilan Hubungan Industrial Pada Pengadilan Negeri Semarang}

Hakim memegang peran penting dalam menegakan hukum dan keadilan, peran hakim juga sangat besar dalam memberikan kepastian hukum. Dalam suatu perkara, hakim dapat memutuskan hal-hal bagi kedua belah pihak dengan melihat dari pembuktian. Setelah terbukti, hakim menemukan hukum dalam perkara yang disengketakan tersebut.

Pada hakekatnya, hakim harus menyelesaikan setiap peristwa konkrit, kasus atau konflik yang dihadapinya. Ada kiranya dasar hukum postif dalam penemuan hukum, seperti dalam Pasal 1 Undang-Ungang Nomor 4 Tahun 2004 tentang PPHI telah ditentukan bahwa kekuasaan kehakiman adalah kekuasaan negara hukum dan keadilan berdasarkan Pancasila demi terselanggaranya negara hukum RI. Merdeka disini berarti bebas. Jadi 
kekuasaan kehakiman adalah bebas untuk menyelenggarakan peradilan. Asas kebebesan peradilan ialah bebes untuk mengadili danbebas dalam campur tangan dari pihak ektra yudisiil. Kebebesan hakim memberi wewenang kepada hakim untuk melakukan penemuan hukum secara leluasa.

Pada dasarnya apa yang dilakukan oleh hakim di persidangan adalah mengkonstatasi peristiwa konkrit, tang sekaligus merumuskan peristiwa konkrit, mengkualifikasi peristiwa konkrit serta mengkonstitusi. Penemuan hukum merupakan proses atau rangkaian kegiatan yang bersifat kompleks, yang dimulai sejak acara jawab-menjawab sempai dijatuhkan putusan. Prosedur penemuan hukum pada pemeriksaan perkara $\mathrm{PHI}$ sama seperti pemeriksaan perdata, dimana penggugat dapat mengajukan gugatan yang berisi peristiwa konkrit yang dijawab oleh tergugat dalam jawabannya yang berisi konkrit pula. Maka hakim perlu mengetahui apa yang sekiranya menjadi sengketa kedua belah pihak. Untuk itu perlu diadakannya acara jawab-menjawab diantara kedua belah pihak.

Hakim harus memperoleh kepastian tentang sengketa atau peristiwa konkrit yang terjadi. Peristiwa konkrit tersebut dirumuskan, akan tetapi yang dirumuskan hanyalah peristiwa hukum yang relevan saja yang harus dibuktikan. Kapan suatu peristiwa konkrit itu relevan? Peristiwa yang relevan adalah peristiwa yang penting bagi hukum, yang berarti peristiwa yang dapat dicakup oleh hukm dan dapat ditundukkan oleh hukum. Peristiwa relevan tersebut nantinya dapat memperngaruhi penyelesaian perkara. Untuk megetahui peristiwa yang relevan hakim terlebih dahulu harus mengetahui peraturan hukumnya.hakim berusaha menemuka hukum dan tidak dapat memutuskan lebih atau kurang dari yang dituntut oleh pihak yang bersengketa. Dari perkara-perkara PHK yang dianalisi dalam skripsi ini, kepastian hukum yang diberikan oleh hakim mengacu pada Undang-Undang Nomor 13 Tahun 2003 dan Undang-Undang Nomor 2 Tahun 2004 serta perUndang-undang lain yang relevan dengan perkara tersebut.

Mengenai hakim tidak dapat memutuskan lebih atau kurang dari yang ditutut pi- hak yang bersengketa, dapat terlihat jelas dalam persoalan kompensasi upah yang harus dibayarkan oleh hakim. Dalam praktiknya, pihak yang di PHK atau pekerja/buruh sering menntut lebih hak-hak normatifnya. Sesuai dengan kebebesan hakim alam arti mikro, hakim PHI tidak begitu saja memenuhinya, hakim berpedoman pada Pasal 156 UndangUndang Nomor 13 Tahun 2003 tentang Ketenagakerjaan. Untuk menemukan hukumnya, terbukti pada saat acara pembuktian dan jawab-menjawab diantara kedua belah pihak, dan hakim PHI menemukan fakta-fakta hukumnya. Berawal dari hal tersebut, akhirnya hakim dapat memutuskan perkara tersebut.

Dalam pertimbangan-pertimbangan, hakim PHI dalam putusan yang penulis analisa, terlebih dahulu mengungkapkan faktafakta hukum dari persidangan hakim yang telah mencerminkan kepastian hukum. Analisis penulis menganai adanya kepsatian hukum terhadap putusan-putusan hakim PHI tersebut adalah sebagai berikut.

Pertama, berdasarkan Perkara No.09/G/2010/PHI.SMG bahwa PHK yang dilakukan oleh tergugat terhadap penggugat tidak sah dan tidak dapat dibuktikan secara hukum sebab PHK dilakukan oleh Penggugat secara lisan oleh tergugat dengan alasan perusahaan sedang mengalami sepi pekerjaan/ sepi order. PHK terhadap penggugat ini dilakukan tidak sesuai dengan prosedur yang seharusnya, tidak ada pemberian surat peringatan terlebih dahulu karena Penggugat tidak mentandatangani surat perjanjian kerja dikarenakan melamar pekerjaan di tempat Tergugat secara lisan. Perjanjian kerja lisan diperbolehkan seperti tercantum dalam Pasal 51 Ayat (1) Undang-Undang Nomor 13 Tahun 2003 yaitu "Penjanjian kerja dibuat secara tertulis atau lisan."

Tergugat menyatakan para Penggugat adalah pekerja borongan yang bekerja pada seorang mandor dan tidak mempunyai daftar abseni hadir kerja di perusahaan dan Tergugat menganggap para Penggugat adalah karyawan harian lepas. Hal ini merupakan perbuatan melawan hukum. Hakim PHI berpendapat berdasarkan KEPMENAKER No. KEP.100/MEN/VI?2004 tentang pelaksanaan perjanjian kerja waktu tertentu pada BAB V 
perihal Perjanjian Kerja Harian Lepas, Pasal 10 ayat (1) : "Untuk pekerjaan-pekerjaan tertentu yang berubah-ubah dalam waktu dan volume pekerjaan serta upah didasarkan pada kehadiran, dapat dilakukan dengan perjanjian kerja harian lepas." Pasal 10 Ayat (2) : "Perjanjian kerja harian lepas sebagaimana dimaksud dalam ayat (1) dilakukan dengan ketentuan pekerja/buruh bekerja kurang dari 21 hari dalam 1 bulan". Pasal 10 Ayat (3) : Dalam hal pekerja/buruh bekerja 21 hari atau lebih selama 3 bulan berturut-turut atau lebih maka perjanjian kerja harian lepas berubah menjadi Perjanjian Kerja Waktu Tidak Tertentu (PKWTT)." Berdasarkan bukti, masa kerja para Penggugat adalah diatas 5 tahun sehingga hal tersebut jelas bertentangan dengan Pasal 10 ayat (3) KEPMENAKER No. KEP.100/MEN/VI/2004 seperti tersebut, dengan demikian perjanjian kerja harian lepas berubah menjadi Perjanjian Kerja Waktu Tidak Tertentu (PKWTT). Berdasarkan Pasal 10 Ayat (3) KEPMENAKER No. KEP.100/MEN/ $\mathrm{VI} / 2004$ status Penggugat bukanlah karyawan harian lepas melainkan sebagai pekerja tetap.

Adapun kepastian hukum yang diberikan hakim $\mathrm{PHI}$ terhadap perkara tersebut memang benar adanya, dimana penulis berpendapat bahwa mengenai kompensasi upah yang wajib dibayarkan Penggugat, harus sesuai dengan UMK Semarang Tahun 2009 sebesar Rp. 838.500-,//bulan. Berdasarkan Pasal 90 Ayat (1) Undang-Undang No.13 Tahun 2003 "Pengusaha dilarang membayar upah lebih rendah dari upah minimum." Oleh karena itu kekurangan upah sebelumnya harus dibayarkan. Dalam perkara ini, gugatan dinyatakan tidak dapat diterima dan nilai gugatanya dibawah Rp. 150.000.00,- maka sesuai dengan Pasal 58 Undang-Undang No. 2 Tahun 2004 tentang PPHI para pihak yang berberkara tidak dikenakan biaya perkara dan membebankan biaya perkara yang timbul dalam perkara ini kepada Negara sebesar Rp. 106.000,-

Kedua, berdasarkan perkara No.38/G/2011/PHI.SMG bahwa PHK yang dilakukan oleh tergugat terhadap penggugat tidak sah dan tidak dapat dibuktikan secara hukum sebab PHK dilakukan oleh Penggugat dengan alasan efisiensi, telah terjadi PHK yang dilakukan Tergugat bukan dikarenakan Penggugat telah melakukan tindakan indisipliner tetapi PHK yang dipaksakan dan diadaadakan atau perusahaan ingin mengefisiensi karyawan, dimana dalam hal ini Penggugat berhak mendapatkan pesangon sesuai ketentuan Undang-Undang No. 13 Tahun 2003 Pasal 164 Ayat (3) yang berbunyi : "Pengusaha dapat melakukan pemutusan hubungan kerja terhadap pekerja/buruh karena perusahaan tutup bukan karena mengalami kerugian 2 (dua) tahun berturut-turut atau bukan karena keadaan memaksa (force majeur) tetapi perusahaan melakukan efisiensi, dengan ketentuan pekerja/buruh berhak atas uang pesangon sebesar 2 (dua) kali ketentuan Pasal 156 ayat (2), uang penghargaan masa kerja sebesar 1 (satu) kali ketentuan Pasal 156 ayat (3) dan uang penggantian hak sesuai sesuai ketentuan Pasal 156 ayat (4)". Sehingga dasar hukum yang dipergunakan dalam perkara ini Hakim menyatakan bahwa gugatan Penggugat adalah Prematur atau Nebis In idem atau kabur (abscuurliber), oleh karena itu gugatan harus dinyatakan tidak dapat diterima (Niet Ontvankelijke Verklaard). Dalam perkara ini, gugatan dinyatakan tidak dapat diterima dan nilai gugatanya dibawah Rp. 150.000.00,maka sesuai dengan Pasal 58 Undang-Undang No. 2 Tahun 2004 tentang PPHI para pihak yang berberkara tidak dikenakan biaya perkara dan membebankan biaya perkara kepada Negara sebesar Rp. 170.800,-

Ketiga, berdasarkan perkara No.14/ Pdt.Sus-PHI/G/2014/PN.SMG, bahwa buktibukti yang diajukan tidak cukup kuat untuk membuktikan bahwa penggugat telah melakukan kesalahan berat dan Penggugat tidak terbukti merugikan perusahaan. Alasan pemutusan hubungan kerja karena dinilai secara keseluruhan merupakan pelanggaran berat karena telah merugikan perusahaan sebesar lebih dari US \$500 akibat dari berbagai kesalahan Penggugat. Dimana waktu perusahaan menagih ke buyer dan buyer tidak mau membayar karena kesalahan dari Penggugat dimana kurang cermat terhadap tanggugjawab yang diberikan perusahaan ke Penggugat. Oleh karena ituhak-hak yang diperoleh Penggugat dalam perkara a quo adalah sesuai dengan ketentuan Pasal 161 
Ayat (3) Undang-Undang No. 13 Tahun 2003 yang berbunyi "Pekerja/buruh yang mengalami pemutusan hubungan kerja dengan alasan sebagaimana dimaksud dalam ayat (1) memperoleh uang pesangon sebesar 1 (satu) kali ketentuan Pasal 156 ayat (2), uang penghargaan masa kerja sebesar 1 (satu) kali ketentuan Pasal 156 ayat (3) dan uang penggantian hak sesuai ketentuan Pasal 156 ayat (4)." Sedangakan untuk perhitungan uang pesangon adalah masa kerja dan upah segala macam tunjangan seperti yang diatur dalam Pasal 157 Undang-Undang No. 13 Tahun 2003 tentang Ketenagakerjaan. Dalam perkara ini, gugatan dinyatakan tidak dapat diterima dan nilai gugatanya dibawah Rp. 150.000.00,maka sesuai dengan Pasal 58 Undang-Undang No. 2 Tahun 2004 tentang PPHI para pihak yang berberkara tidak dikenakan biaya perkara dan membebankan biaya perkara kepada Negara sebesar Rp. 181.000,-

Akan tetapi, dalam persoalan menganai kepastian hukum ini ada pertimbangan sulit menganai hal tersebut. Apabila nilai suatu kepastian hukum itu lebih ditonjolkan, tentu saja akan menggeser nilai kepastian dan nilai keadilan. Sebaiknya apabila memperhatikan hal-hal berguna dan tidak mempertimbangkan hal-hal yang berguna dan tidak mempertimbangkan hal-hal yang konkrit, maka akan menggeser nilai kepastian dan keadilan. Adanya dominasi keadilan, mengandung resiko bahwa kepastian hukum akan terlalu jauh dikorbankan. Untuk itu haruslah diperhatikan permasalahan penemuan hukum bebas oleh hakim.

Oleh karena itu, kesimpulan akhir dari penulis berdasarkan putusan-putusan hakim PHI pada PN Semarang, bahwa kepastian hukum tidak dapat tercapai hanya dengan menelaah setiap peraturan-peraturan yang ada. Dalam hal ini, permasalahan pokok yang harus dipecahkan adalah masalah kemasyarakatan yang konkrit. Apabila dari peristiwa-peristiwa konkrit tersebut ada yang tidak diatur oleh suatu peraturan, maka tugas hakimlah untuk menentukan hukumnya. Undang-Undang sendiri lebih mengarah kepada usulan penyelesaian sebagai pedoman untuk menemukan hukum, hal ini disebabkan karena Undang-Undang bukanlah satu- satunya sumber hukum.

\section{Simpulan}

Berdasarkan hasil penelitian, analisis dan pembahasan oleh peneliti maka dapat disimpulkan sebagai berikut. Pertama, pemenuhan hak pekerja/buruh yang mengalami Pemutusan Hubungan Kerja berdasarkan Undang-Undang Nomor 2 Tahun 2004 tentang Penyelesaian Perselsihan Hubungan Industrial. Hak pekerja/buruh yang tercantum dalam perjanjian kerja jika terjadi PHK maka pekerja/buruh hanya memperoleh uang pesangon dan uang penggantian hak sesuai dengan ketentuan perUndang-Undang yang berlaku. Ada beberapa alasan dan kondisi tertentu yang menyebabkan dapat berakhirnya hubungan kerja, baik yang terletak pada diri pekerja/buruh maupun penguasaha. Apabila melihat dari putusan-putusan hakim PHI menganai kasus-kasus PHK, maka ada beberapa penyebab terjadinya PHK tersebut antara lain PHK yang dilakukan Perusanaan secara lisan, adanya efisiensi yang dilakukan perusahaan yang menyebabkan terjadinya PHK, dan karena ada kesalahan berat yang dilakukan pekerja/buruh.

Kedua, PHK selalu memilik akibat hukum, baik terhadap pegusaha maupun terhadap pekerja/buruh. Akibat hukum yang dimaksud adalah bentuk pemberian kompensasi upah kepada pekerja/buruh yang hubungan krjanya terputus dengan pengusaha. Berdasarkan putusan-putusan yang dianalisi dalam skripsi ini, maka terhadap kompensasi upah yang harus diberikan pengusaha kepada pekerja/buruh akibat terjadinya PHK, hakim berusaha bertindak adil dalam pertimbangan yang dituangkan dalam "pokok perkara", sehingga dapat mencapai dasar penyelesaian sengketa. Menganai peran hakim dalam memberikan kepsatian hukum terhadap kasus-kasus PHK terlihat dalam setiap putusannya. Kepastian hukum dapat berarti keharusan adanya suatu peraturan.

Walaupun peraturan-peraturan mengenai hukum ketenagakerjaan tidak terhimpun dalam suatu kodifikasi, peraturan tersebut tetep dapat memberikan suatu kepastian hukum. Terkecuali dalam Undang-Undang 
tidak mengaturnya, maka hakim baru menemukan hukumnya (sesuai dengan ketentuan Pasal 16 ayat (1) Undang-Undang Nomor 4 Tahun 2004). Selain itu, kepastian hukum dapat berarti memberikan perlindungan hukum terhadap individu yang disewanang-wenangkan oleh individu. Maka dapat dilihat dalam putusan akhirnya, bahwa setiap tindakan-tindakan individu yang semena-mena, seperti salah satunya adalah PHK secara sepihak tanpa membayarkan hak-hak normatif pekerja, maka hakim berupaya untuk mengabulkan tuntutan dari individu (pekerja/buruh) yang terlarang, walaupun ada ketentuan hakim $\mathrm{PHI}$ tiadak dapat memutuskan lebih atau kurang dari apa yang dituntut olehnya.

\section{Daftar Pustaka}

Budiono, R. Abdul; Hukum Perburuhan; Jakarta Barat; PT Indeks; 2011

Hardijan, R. 2011. Hukum Ketenagakerjaan; Bogor: Ghalia Indonesia.

Husni, L., 2003. Pengantar Hukum Ketenagakerjaan Indonesia; Jakarta; PT Raja Grafindo Persada.

Libertus, J., 2007. Hak-Hak Pekerja Bila di PHK; Tangerang; Praninta Offset.

Marbun, R. 2010. Jangan Mau di PHK Begitu Saja; Jakarta Selatan; Visi Media.

Midah, A. 2010. Hukum Ketenagakerjaan Indonesia: Dinamika dan Kajian Teori; Bogor: Ghalia Indonesia

Sidabutar, E. S., 2004. Pedoman Penyelesaian PHK; Jakarta; PT. Raja Grafindo Persada; .

Sunyoto, D., 2010. Hak Dan Kewajiban Bagi Pekerja Dan Pengusaha; Yogyakarta; Pusaka Yustisia.

Wijayanti, A., 2009. Hukum Ketenagakerjaan Pasca Reformasi; Jakarta; PT. Sinar Grafika.

Wijayanti, A., 2012. Sinkronisasi Hukum Perburuhan
Terhadap Konvensi ILO; Bandung: Karya Putra Darwati Bandung.

Zainal, dkk., A. 1994. Dasar-Dasar Hukum Perburuhan; Jakarta; PT Raja Grafindo Persada.

Zaeni, A. 2008. Hukum Kerja: Hukum Ketenagakerjaan Bidang Hubungan Kerja; Jakarta: Rajawali Pers.

Peraturan PerUndangan-Undangan :

Pancasila dan UUD 1945

Undang-Undang Nomor 21 Tahun 2000 tentang Serikat Pekerja/ Serikat Buruh

Undang-Undang Nomor 13 Tahun 2003 tentang Ketenagakaerjaan

Undang-Undang Nomor 2 Tahun 2004 tentang Penyelesaian Perselisihan Hubungan industrial

Kepmen No. 255 Tahun 2003 tentang Tata Cara Pembentukan dan Susunan Keanggotaan Lembaga Kerjasama Tripartit

Kepmennaker RI No. KEP-105/MEN/2000 tentang Penyelesaian Pemutusan Hubungan Kerja dan Penetapan Uang Pesangon, Uang Penghargaan Masa Kerja dan Ganti Kerugian di Perusahaan.

Keputusan Menteri Tenaga Kerja RI Nomor: KEP-17/ MEN/2000 tentang Perbaikan Penulisan Pada Pasal 1 Angka 12 dan Pasal 18 Ayat (1) huruf g, h dan i Keputusan Menteri Tenaga Keja RI Penyelesaian Pemutusan Hubungan Kerja dan Penetapan Uang Pesangon, Uang Penghargaan Masa Kerja dan Ganti Kerugian di Perusahaan

Putusan MK No. 012/PUU-I/2003 atas Hak Uji Materiil Undang-Undang Nomor 13 Tahun 2003 tentang Ketenagakerjaan terhadap UndangUndang Tahun 1945

Surat Edaran Menteri Tenaga Kerja dan SE.13/MEN/ $\mathrm{SJ}-\mathrm{HKI} / \mathrm{I} / 2005$ tentang Putusan MK atas Hak Uji Materiil Undang-Undang Nomor 13 Tentang Ketenagakerjaan terhadap Undang-Undang Tahun 1945 